\title{
OBITUARY
}

\section{SIR READER WILLIAM BULLARD}

The Governing Body of the School has been fortunate in the number of distinguished public servants who, after retiring, have placed their wisdom and experience at the service of the School. Not least among them was Sir Reader Bullard, who died on 24 May 1976 at the age of 90 . His appointment in 1953 to the Governing Body, of which he was Vice-chairman from 1954 to 1965, was particularly appropriate, not only because of the qualities which he brought to this work, but also because he had served many years in countries the study of which closely concerns the School. It was also appropriate because in 1947 he joined and later became Chairman of a Treasury Committee appointed to make recommendations for the grant of studentships to candidates wishing to take up the study of Oriental, Slavonic, East European, and African languages and cultures, which developed out of the Interdepartmental Commission presided over by Lord Scarbrough.

Sir Reader's parents, to whom he was deeply attached, were, as he states in his autobiography, The camels must go, a remarkable pair, distinguished by qualities of self-sacrifice and endurance. His father, a radical individualist, was, by the time Sir Reader was old enough to understand, in regular employment as foreman on the British and Foreign Wharf, but when Sir Reader was born he was a casual labourer at the docks. On that day he walked from Walthamstow to the London docks in the hope of being taken on for a day's work, helping to load or unload some vessel. 'Having failed to catch the foreman's eye, and holding that it was the willingness of casual labourers to hang about all day that encouraged the employers to depend on casual labour, he walked home again, and having earned no money, he bought no food.' Throughout Sir Reader's childhood, the family lived on a very narrow margin.

In January 1906 Sir Reader passed into the Levant Consular Service by what he described as 'a curious steeplechase', which included the winning of a scholarship to Bancroft, the Drapers' School at Woodford, employment at the age of 15 as a pupil teacher, a correspondence course, night school, and, at 18, an assistant mastership at a school in the poorest part of Walthamstow. A less single-minded and determined person than he might well have fallen, had he ever started, long before the winning-post. He went up to Cambridge with four others as a student interpreter to study Oriental languages for two years. Arabic, Persian, and Turkish were all begun on the same day. Of Professor E. G. Browne, who was their director of studies, he writes, ' His knowledge was so vast that the difficulties of beginners were incredible to him. When we had been struggling with our three new languages for a few weeks he seemed distressed that we could not translate The Thousand and One Nights from the Arabic at sight. As a teacher in the narrow sense he was a joke, but this mattered little in the light of the erudition which fountained from him in amusing and stimulating coruscations. A skilful question would set him off in pursuit of some golden hare-Persian poetry, the early caliphs or the Abbasids of Baghdad, and the end of the hour would come all too soon. I think that a few systematic lectures on Islam might have been useful to us, but Browne had to be taken for what he was: a meteor, not a locomotive'.

Sir Reader's first post was Turkey, where he served from 1908 to 1914, at Constantinople, Trebizond, and Erzerum. He arrived in time to see the last 


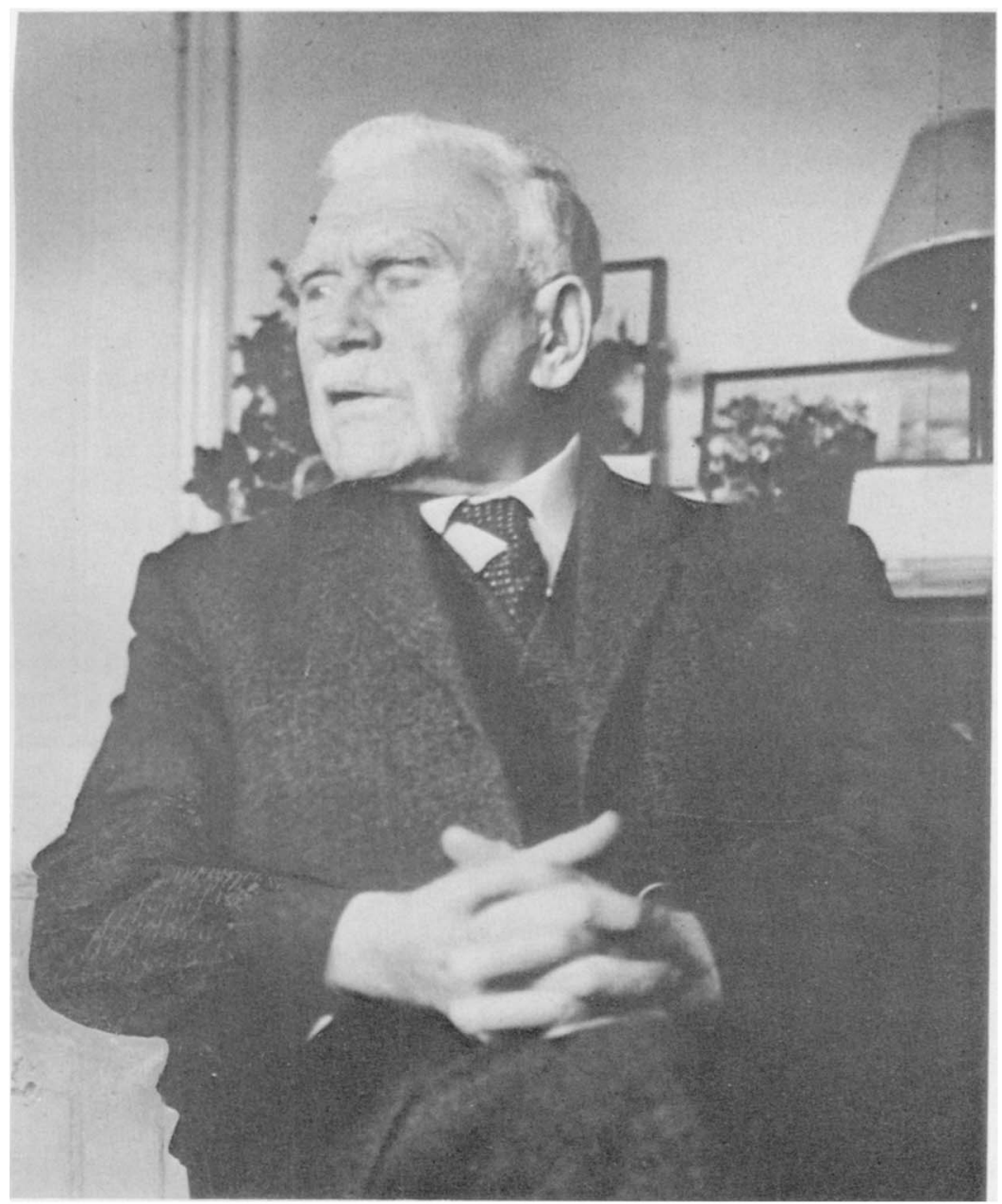

Sir Reader William Bullard

BSOAS XI 
few weeks of the régime of Abdul Hamid and to witness the Young Turk Revolution. When the first World War broke out, he was in Bașra, where he had been sent shortly before. He spent the next four years in Iraq, first with the Indian Expeditionary Force and then on the staff of Sir Percy Cox, who was political adviser to the army and in charge of civil administration. In 1916 Sir Reader was given a C.I.E., which, with typical modesty, he describes as ' an earthquake honour, the kind which is conferred when some convulsion of nature or some extravagant act of man brings one out of obscurity for a moment'. The duties he carried out as a Political Officer were numerous and varied. Much of the work consisted in trying to meet the needs of the army and in local tasks. The Political Officer 'bought large numbers of sheep (some cattle, too, when there were any to be had) for the army; he had to induce the local people to bring in fish, eggs, and chickens for the troops in the area at prices the troops would not think exorbitant; he had to prevent the Arabs from stealing timber from the railway bridges, and to arbitrate on compensation when the army wanted to cut down a palm tree, demolish a wall, or hire boats. He had to help to maintain the blockade against the Turks, by issuing licences for the purchase in Basra of such quantities of tea, sugar, piece goods and other necessities as would supply his district reasonably well but leave no margin to be smuggled out to the Turks'. He was sent to Baghdād after its capture in March 1917 and later started up the civil administration in Kifri and Mawsil. In the autumn of 1918 he went briefly as temporary Oriental Secretary with Sir Percy Cox to Tehran. Coming back to Mawșil, he went home for a few weeks on leave, his first for six years. On his return he was sent to Baghdād as Deputy to the Revenue Secretary for the occupied territory, and in May 1920 became Military Governor of Baghdād. When he left Iraq in December, the country had been completely changed from the remote neglected province to which he had come some six years earlier.

From 1921 he spent an arduous two years in the newly formed Middle East Department of the Colonial Office. He was offered, meanwhile, but declined, the post of adviser to the Ministry of the Interior in Iraq. In 1923 he returned to his own service and was appointed Consul at Jidda, at a time when the new kingdom of the Hijāz was trying to find its feet. The post was made the more interesting because there was no embassy or legation between the consulate and the Foreign Office. The work was demanding and difficult. King Husayn was both obstinate and unpredictable. Living conditions were hard, distractions few. It was unsafe to go more than a mile or so from the town walls. 'One could', as Sir Reader sometimes said, ' walk to one heap of sand rather than another and distinguish Sunday from weekdays by having three biscuits for tea instead of two.' In his post report in answer to the question "What foreign institutions are there-churches, banks, clubs, etc.', he wrote 'there are two foreign institutions in Jedda : a bank, which is closed, and a cemetery, which is open'.

Sir Reader's next post was that of consul in Athens. He arrived in 1925 at a time of crisis, arising from the attempt to absorb over a million Greek refugees from Turkey. For the next three years he was engaged in consular work. In 1928, on being told that he was to be transferred to Addis Ababa, he ordered from home an Amharic grammar and set to work on his eleventh language. Although he had great feeling for the English language and was impatient of its impoverishment either by the misuse of words or the use of heavier words than the sense required, he was not 'one of those people who pick up a language by just hearing it spoken'. He had, however, the capability 
of learning difficult languages in case of need. On arrival in Ethiopia, finding that Arabic was the lingua franca of business, he gladly abandoned Amharic, though his knowledge of it was, in fact, good. In Addis Ababa he added to his already varied equipment judicial experience in the capitulatory courts.

When in the spring of 1930 there were signs that relations with the Soviet Union, which had been broken off at the time of the Arcos raid, might be renewed, Sir Reader asked the Foreign Office for a post in Russia. One of his reasons in so doing was an interest in seeing the Soviet experiment at close quarters, an experiment he found 'the more interesting because the Soviet Marxists did not admit that it was an experiment: like contractors building a bridge designed by a qualified engineer they held that they were constructing society (in so far as it was not inexorably constructing itself) according to an infallible formula'. To read about the Tsarist régime fascinated him, but the corruption with which it was riddled horrified him. He wanted to see what success the Soviet leaders, who claimed to be uprooting that abuse and to be pursuing other desirable objects, were having, and what the Soviet people had to pay for it. The four years from November 1930 which he spent in the Soviet Union as Consul-General, first in Moscow and then in Leningrad, coincided with the ending of the first five-year plan and the beginning of the second. They left him with no illusion as to Soviet methods and policy-its insensibility to human suffering, its disregard of the individual, its twisting of the public mind by propaganda, and the atmosphere of humbug to which the Soviet citizen had to accustom himself. It was, thus, no surprise to him that the policy of the Soviet authorities in Persia, where they occupied the northern provinces during the second World War, should have been to weaken and humiliate the Persian government and its officials in the eyes of the public.

In 1934 Sir Reader was transferred to Rabäț as Consul-General. Like Jidda, the consulate in Ribāt was directly dependent on the Foreign Office. Much of his time there, as it had been in Addis Ababa, was occupied by work resulting from the Capitulations, which were still in force in the French Zone. He liked the French and enjoyed his two years in Morocco. Perhaps because of this, he found Churchill's proposal for an Anglo-French union, made at the time when France was on the edge of defeat, attractive. The possibility of the fusion of the better qualities of the two peoples, the intellectual powers of the French and the political good sense of the British, excited him. But would it work, he asked. Suppose the child had the face of Bernard Shaw and the brains of Isadora Duncan?

On his transfer from Rabāt to the post of minister in Saudi Arabia in 1936, Sir Reader was made a K.C.M.G. Conditions in Jidda had greatly improved since his first posting there. During his stay of three years he established relations of mutual respect and trust with Ibn $\mathrm{Sa}^{\prime} \bar{u} \mathrm{~d}$, whom he both admired and liked, though there were features of life in Saudi Arabia, such as the existence of slavery and the corruption in the civil service, which he abhorred. The great bone of contention with the Arab world at this time was Zionism. Sir Reader was critical of the politicians who passed the Balfour Declaration and the shifting, ambiguous policy to which it gave rise. The Palestine question continued to disturb him, and the Suez adventure he found more and more difficult to understand the more it was explained.

In December 1939, Sir Reader proceeded to Tehran, his last post. He remained there until December 1945, first as minister and from 1943 as ambassador. For his part in the Tehran Conference in 1943 he was recommended by Sir Winston Churchill for a K.C.B. His judgement, persistence, skill 
in negotiation, and imperturbability were invaluable during the difficult wartime years. He never became fully at home in Persian as he had been in Turkish, Arabic, and Russian, though he was well enough acquainted with the language to spot any mistranslation by an interpreter. Perhaps its subtle nuances were not wholly to his taste, but more probably the reason was that he did not serve in Persia, apart from brief tours in 1918 and 1920, until 1939 ; and he never developed for Persia the same warm feelings which he had for the Arab world. The apparent deviousness of the Persians and their unwillingness to accept responsibility were not congenial to him, though he found their readiness to see a joke against themselves attractive. Some Persians found him austere and, perhaps, resented that they could not take him in. He had, nevertheless, many Persian friends and was widely respected, and rightly so, for in spite of the continual harassment by the Russians, he fought toughly, so far as the exigencies of the situation permitted, for their interests, to alleviate the hardships which the war entailed for them and to resist any curtailment of their independence or lessening of the authority of their government.

In August 1921 Sir Reader married Miriam Catherine, the fourth daughter of A. L. Smith of Balliol, a marriage which was itself happy and gave to him through his wife's family 'the freedom of a widespread and distinguished community'. He was devoted to his family but unflinchingly faced the need for a long series of family separations, which began in 1923 when he was appointed to Jidda. He was proud of his family and rejoiced in their achievements, and, later, in those of his grandchildren. When after much debate it was decided that his wife and son should return home from Athens in June 1925-his second son was to be born later that year-he wrote, "Thus it came about, fittingly, that the son who was to be captain of the OURFC was born in Oxford, while the third son, born later in Athens, was to read "Greats" and to become a Fellow of All Souls'. His fourth son was born in Addis Ababa. In 1930, when posted to Russia, he bought a house in Oxford where his wife and children could live for the next few years. By the time he left Russia, he writes, "The birth of a daughter had increased the weight of our anchor in England, and the arrangement by which my family remained at home became permanent '. His eldest son died in 1964 and his wife in 1973. His daughter and daughters-in-law, however, were able to make his remaining years happy and comfortable.

After he retired, Sir Reader continued to live a full and busy life. He was Director of the Institute of Commonwealth Studies at Oxford for five years, Chairman of the Libyan Currency Commission, and the British member on the arbitration tribunal set up to study and decide the frontier dispute about the Buraymi oasis, to which the Saudi Arabian government laid claim in 1949. He resigned from this after it became clear that attempts were being made to tamper with the impartiality of the tribunal. He had a keen belief in the value of local government and the work of voluntary societies, and was elected to his Rural District Council and Parish Council, to the affairs of which he gave much time. He was also in demand as a lecturer, broadcaster, and writer. $\mathrm{He}$ wrote an excellent popular book, Britain and the Middle East, and edited the third edition of the Chatham House volume, The Middle East: a political and economic survey. His autobiography, The camels must go, once described as ' that most readable and modest of biographies, a book which should be compulsory reading for all young men who may be inclined to take for granted the benefits they enjoy in the Welfare State', was published in 1961. It is an enchanting book, full of wisdom, common sense, and gentle humour. Of the 
countless persons who crowd its pages, some well known, others less so or quite unknown, he writes with generosity, tolerance, and compassion. The book is dedicated 'to the memory of HBM Levant Consular Service 1876-1936'. This, too, is typical: Sir Reader was proud of his service and grateful for the opportunities it gave him for service to his country. Not least, perhaps, he rejoiced in the many colleagues with whom he shared official experiences and the way of looking at things that matter, and in the many friends he made during his years abroad with whom differences of language, religion, and politics still left much common ground in opinion and feeling.

Sir Reader was, as his obituary notice in the Times stated, 'in all senses of the word a full man, interested in every manifestation of mankind'. He was a quick worker and was indefatigable in his industry. His honesty was unflinching, his hatred of injustice uncompromising. His strictest censure and disapproval was for humbug, hypocrisy, double-dealing, and calculating worldliness. His outlook was stern in its demands, but he was always ready to see the best in others. His joy in the simple things of life was unlimited and his kindliness and consideration, shown in the most unobtrusive of ways, were boundless. He was pre-eminently one in whom self was forgotten.

ANN K. S. LAMBTON 